\title{
TINGKAT PENCEMARAN LOGAM BERAT PADA EKOSISTEM WADUK DI JAWA BARAT (SAGULING, CIRATA, DAN JATILUHUR)
}

\author{
Sutrisno*), Santosa Koesoemadinata*), dan Imam Taufik*)
}

\begin{abstract}
ABSTRAK
Ekosistem waduk di Jawa Barat (Saguling, Cirata, dan Jatiluhur) merupakan perairan yang sangat potensial bagi pengembangan usaha budi daya ikan air tawar dengan sistem keramba jaring apung (KJA). Ekosistem tersebut menghadapi ancaman masuknya cemaran logam berat dari limbah pemukiman, perkotaan, dan industri di sekitarnya, yang dapat berpengaruh negatif terhadap produktivitas perikanan di perairan tersebut. Kegiatan penelitian telah dilakukan untuk menentukan tingkat pencemaran enam logam berat ( $\mathrm{Mn}, \mathrm{Cd}, \mathrm{Cr}, \mathrm{Cu}, \mathrm{Pb}$, dan $\mathrm{Fe}$ ) di ekosistem waduk di atas, untuk mendapatkan data dasar sebagai acuan dalam manajemen perikanan budi daya ikan air tawar yang rasional dan lestari di perairan tersebut. Hasil penelitian menunjukkan bahwa tingkat residu rata- rata keenam logam berat di ketiga waduk tersebut pada umumnya masih sesuai baku mutu air untuk perikanan budi daya air tawar (Peraturan Pemerintah RI No. 82 Tahun 2001). Tingkat residu logam berat di tiga waduk adalah sebagai berikut: Cirata $>$ Saguling $>$ Jatiluhur. Tingkat konsentrasi logam berat $\mathrm{Fe}>\mathrm{Mn}>\mathrm{Cr}>\mathrm{Pb}>\mathrm{Cu}$ $>\mathrm{Cd}$. Hasil penelitian juga menunjukkan bahwa residu logam berat dalam air < ikan < sedimen.
\end{abstract}

\section{ABSTRACT: Levels of heavy metal pollution in the reservoir ecosystems of West Java (Saguling, Cirata, and Jatiluhur). By: Sutrisno, Santosa Koesoemadinata, and Imam Taufik}

Reservoir ecosystems in West Java (Saguling, Cirata, and Jatiluhur) are potentially suitable waterbodies for the development of floating cage culture. However these aquatic ecosystems are increasingly endangered by heavy metal pollutants introduced from the neighboring rural development, cities and industrial establishments, which may eventually effects, quantatively as well as qualitatively, the productivity of fisheries in the system. Studies to determine the residu levels of highly toxic metals ( $\mathrm{Mn}, \mathrm{Cd}, \mathrm{Cr}, \mathrm{Cu}, \mathrm{Pb}$, and $\mathrm{Fe}$ ) in water, sediment and fish were carried out in the reservoirs to obtain to define the extent of heavy metal pollution in the aquatic ecosystems. Results of this study revealed that the residue level of the six heavy metals measured in the three reservoirs were still within acceptable limits for fish culture according to the water quality standard issued by the government (Indonesian Government Regulation Number 82 Year 2001). The potential metal pollution in the three reservoirs was noted as follows: Cirata > Saguling > Jatiluhur. The amounts of heavy metal concentration detected in the reservoirs were as follows: $\mathrm{Fe}>\mathrm{Mn}>\mathrm{Cr}>\mathrm{Pb}>\mathrm{Cu}>\mathrm{Cd}$. The study also demonstrated that the increase sequent of heavy metal residues in the reservoirs was: water < fish < the sediment.

KEYWORDS: heavy metal, reservoir, West Java, residu levels, pollution

*) Peneliti pada Balai Riset Perikanan Budidaya Air Tawar, Bogor 


\section{PENDAHULUAN}

Waduk Saguling, Cirata, dan Jatiluhur adalah lingkungan perairan yang rentan terhadap pencemaran berbagai jenis bahan kimia atau yang dikenal dengan istilah B3 (Bahan Berbahaya dan Beracun). Hal ini terjadi karena ekosistem ketiga waduk tersebut berdekatan dengan lingkungan/ komunitas pemukiman, pertanian, dan industri yang dalam melakukan aktivitasnya banyak menggunakan berbagai jenis bahan kimia. Introduksi limbah kimia ke dalam waduk tidak dapat dihindari, karena sumber air waduk sebagian berasal dari aliran sungai yang juga merupakan tempat pembuangan limbah perkotaan, pertanian, dan industri yang berada di sepanjang Daerah Aliran Sungai (DAS).

Ada berbagai jenis bahan cemaran yang termasuk B3, di antaranya adalah golongan logam berat seperti cadmium (Cd), tembaga $(\mathrm{Cu})$, dan timbal $(\mathrm{Pb})$ yang berdaya racun tinggi dan mudah diperoleh pada lingkungan akuatik. Bahan- bahan tersebut merupakan senyawa kimia yang digunakan dalam kegiatan industri, pertambangan, dan rumah tangga, sehingga tingkat pencemarannya dalam perairan akan semakin tinggi seiring dengan meningkatnya aktivitas manusia.

Pencemaran ekosistem waduk oleh logam berat pada konsentrasi tertentu dapat menimbulkan berbagai gangguan ekologis di lingkungan perairan tersebut. Masalah pencemaran ini dapat menimbulkan dampak destruktif terhadap keanekaragaman sumber hayati perikanan dan produktivitas perikanan (Kumar \& Pant, 1994). Keracunan kadmium pada udang putih (Penaeus merguiensis) menyebabkan degradasi dan nekrosa jaringan insang dan hepatopankreas yang dapat menyebabkan kematian (Darmono, 1990) dan pada konsentrasi subletal $(10 \mu \mathrm{g} / \mathrm{L})$ akan menimbulkan gangguan ionik pada ikan mujair (Oreochromis mossambicus), yakni menurunkan plasma total Ca, plasma osmolaritas, dan ion Na. Merkuri dapat menyebabkan kerusakan pada insang, dan menghambat sistem kerja enzim (Darmono, 1990), sedangkan keracunan timbal dapat menimbulkan gejala penyakit Plumbism dan secara kronis dapat menyebabkan kerusakan pada ginjal/ nephritis (Darmono, 2001).

Potensi bahaya residu logam berat terhadap kesehatan manusia telah banyak diketahui (Suwarna et al., 1981), yakni antara lain sebagai penyebab gangguan ginjal dan hati, penyakit anemia, dan kanker. Menurut
Sumekar (1999) dalam Sutamihardja (2001), di dalam tubuh manusia logam berat akan mengalami proses pemecahan/ peruraian menjadi ion-ion di dalam usus. Selanjutnya ion-ion tersebut masuk ke dalam darah dan mencapai target organ sesuai dengan jenis logam berat. Yang menjadi organ target pada umumnya adalah hati, otak, ginjal, dan sumsum yang di dalam organ target tersebut ion logam berat akan berikatan dengan ion-ion sulfida yang terkandung dalam protein. Senyawa S- logam inilah yang dapat menimbulkan kerusakan atau tidak berfungsinya organ target yang diserang.

Dengan dikembangkannya perairan Waduk Saguling, Cirata, dan Jatiluhur sebagai pusat kegiatan budi daya ikan dengan sistem keramba jaring apung masalah pencemaran lingkungan perairan oleh logam berat di perairan tersebut perlu dicermati lebih serius.

Penelitian pencemaran di perairan perikanan budi daya belum banyak dilakukan, meskipun kasus pencemaran air sungai, danau, dan waduk oleh bahan kimia, antara lain logam berat yang dapat menimbulkan kerugian pada usaha budi daya perikanan, telah sering terjadi dan dilaporkan. Oleh karena itu, data dasar dan informasi mengenai tingkat pencemaran logam berat di suatu perairan perikanan budi daya sangat diperlukan agar dapat dilakukan upayaupaya pengelolaan perairan tersebut yang rasional dan efektif.

\section{BAHAN DAN METODE}

\section{Lokasi Penelitian}

Pengambilan sampel air, lumpur, dan ikan dilakukan masing-masing pada 4 lokasi di Waduk Saguling, 5 lokasi di Cirata, dan 9 lokasi di Jatiluhur (Lampiran 1, 2, 3, dan Gambar 1, 2, 3). Lokasi ini ditentukan berdasarkan pertimbangan bahwa daerah tersebut sebagai areal sumber pencemaran, kegiatan akuakultur, dan kepentingan lainnya. Lokasi tersebut juga digunakan oleh Instalasi Penelitian Perikanan Tangkap dan Perum Otorita Jatiluhur untuk melakukan pemantauan kualitas air secara berkala, sehingga data yang diperoleh dapat dijadikan data tambahan dalam mengevaluasi hasil pemantauan tersebut.

\section{Pengambilan Sampel}

Pengambilan sampel air, lumpur, dan ikan dilakukan pada bulan Juli, Agustus, dan November 2002. Kandungan logam berat yang dianalisis adalah $\mathrm{Mn}, \mathrm{Cd}, \mathrm{Cr}, \mathrm{Cu}, \mathrm{Pb}$, dan $\mathrm{Fe}$. 


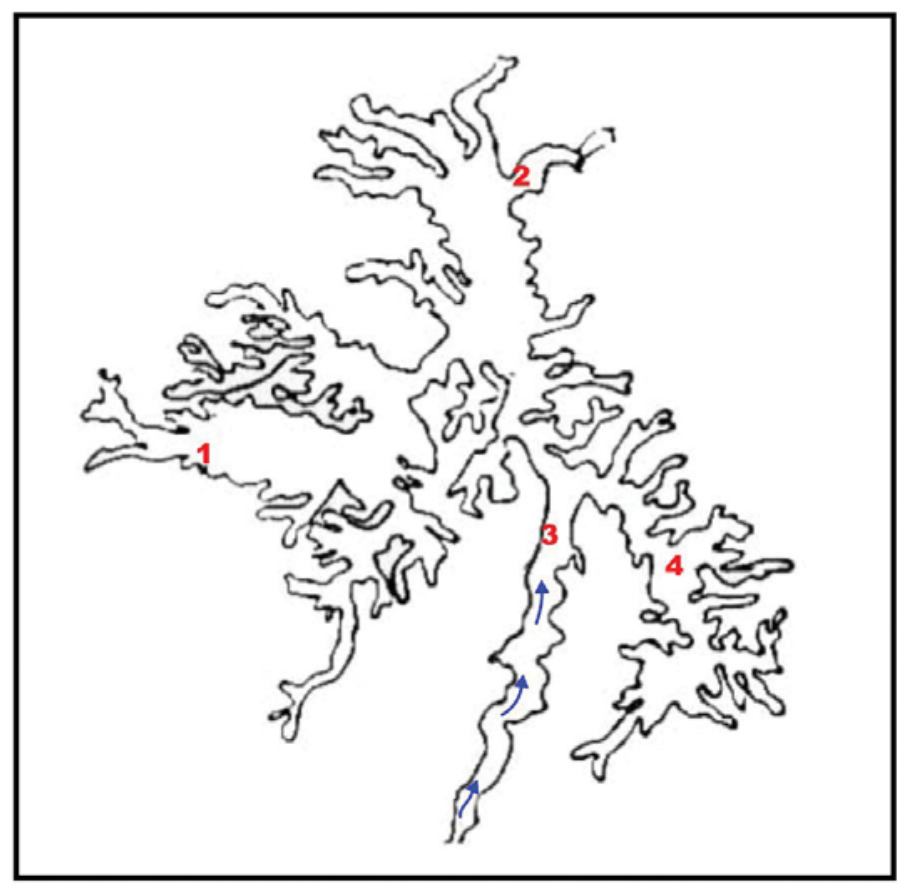

Keterangan (Remark):

Luas waduk 5.600 ha (Reservoir area is 5,600 ha)

1. Bongas

2. Dam

3. Maroko

4. Bunder

$\rightarrow$ Sungai Citarum (Citarum river)

Gambar 1. Lokasi pengambilan contoh air, lumpur, dan ikan di Waduk Saguling

Figure 1. Sampling locations of water, mud, dan fish at Saguling reservoir

Sampel air diambil dari permukaan, kedalaman $4 \mathrm{~m}, 8 \mathrm{~m}$, dan dasar waduk (pada kedalaman 26-40 m) sebanyak masingmasing $500 \mathrm{~mL}$. Sampel air permukaan dan sampel air dari kedalaman $4 \mathrm{~m}$ disatukan menjadi sampel komposit, hal yang sama dilakukan terhadap sampel air dari kedalaman $8 \mathrm{~m}$ dan dari dasar waduk. Sampel sedimen dasar waduk diambil sebanyak $200 \mathrm{~g}$, dan sampel ikan diperoleh dari keramba jaring apung serta dari hasil penangkapan, masingmasing sebanyak $100 \mathrm{~g}$.

\section{Analisis Sampel}

Terhadap setiap sampel yang diperoleh dilakukan ekstraksi, preparasi, dan identifikasi dengan menggunakan alat Spektrometri Serapan Atom atau AAS (Atomic Adsorption Spektrophotometer).
Preparasi sampel dilakukkan dengan cara oksidasi basah, yakni dengan menambahkan $5 \mathrm{~mL} \mathrm{HNO}_{3}$ dan $0,5 \mathrm{~mL} \mathrm{HClO}_{4}$, kemudian dibiarkan satu malam, dan esoknya dipanaskan dalam digestion blok dengan suhu $100^{\circ} \mathrm{C}$ selama satu jam, yang kemudian ditingkatkan menjadi $150^{\circ} \mathrm{C}$ dan $200^{\circ} \mathrm{C}$. Sisa ekstrak $(0,5$ $\mathrm{mL}$ ) dibiarkan dingin, kemudian diencerkan dengan air bebas ion hingga $50 \mathrm{~mL}$. Ekstraks digunakan untuk pengukuran residu logam berat dengan alat AAS yang menggunakan nyala campuran udara- asetilen.

\section{HASIL DAN BAHASAN}

Kandungan residu rata- rata logam berat dalam air, sedimen, dan ikan di perairan Waduk Saguling, Cirata, dan Jatiluhur tertera pada Tabel 1. Residu logam berat dalam air di permukaan waduk umumnya lebih tinggi 


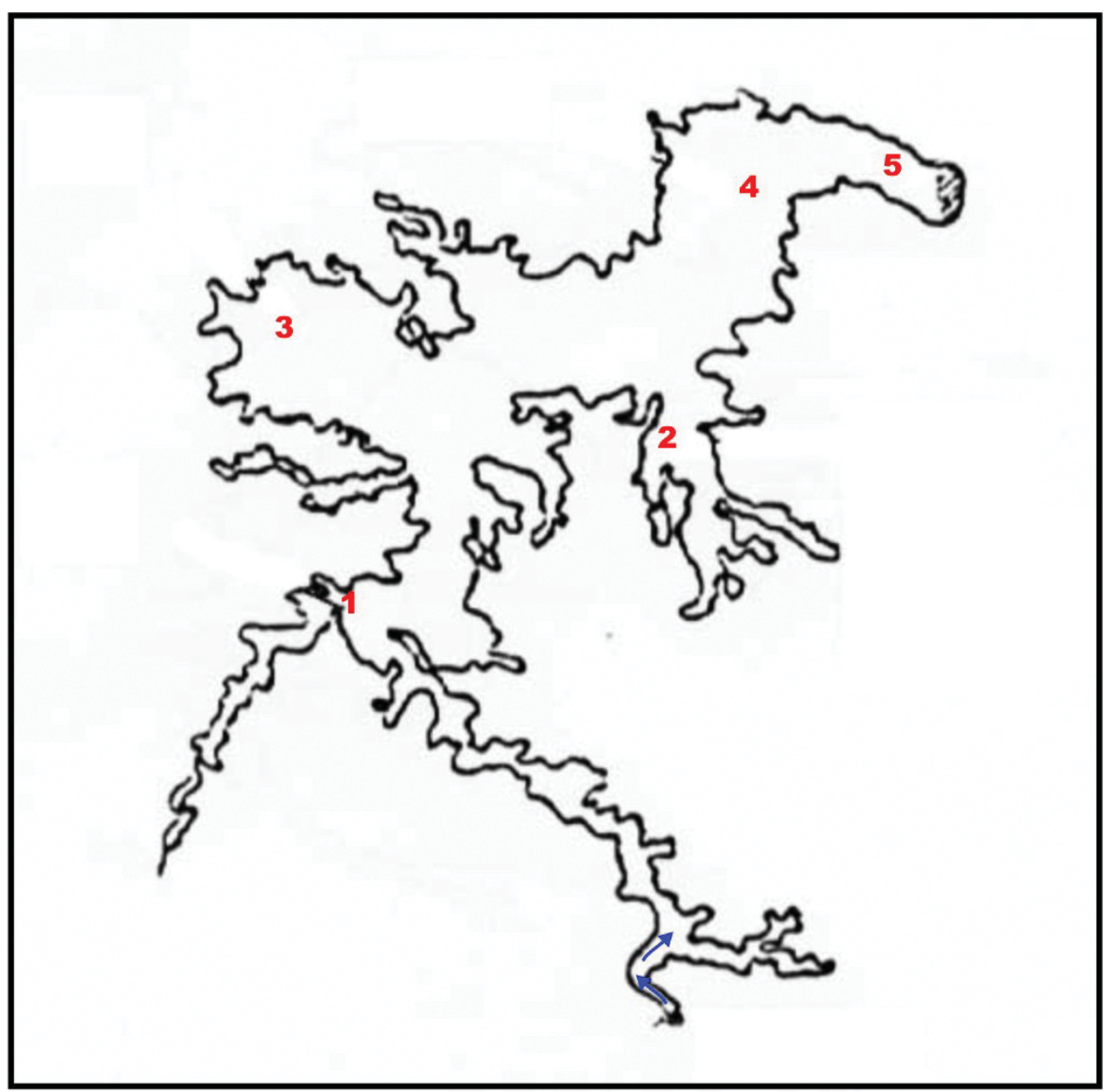

Keterangan (Remark):

Luas waduk 6.200 ha (Reservoir area is 6,200 ha)

1. Jangari

2. Cipicung

3. Maleber

4. Tegal datar

5. Dam

$\rightarrow$ Sungai Citarum (Citarum river)

Gambar 2. Lokasi pengambilan contoh air, lumpur, dan ikan di Waduk Cirata

Figure 2. Sampling location of water, mud, and fish at Cirata reservoir

dibanding di bagian dasar. Akan tetapi di tempat- tempat tertentu di mana terjadi percampuran air yang sempurna, karena ada arus, perbedaan ini tidak jelas. Hal sebaliknya juga dapat terjadi, di mana konsentrasi logam di permukaan lebih tinggi dari dasar waduk, yang kemungkinan disebabkan adanya aliran umbalan (upwelling).

Data dalam Tabel 1 menunjukkan bahwa kisaran konsentrasi logam berat $\mathrm{Mn}, \mathrm{Cd}, \mathrm{Cr}$,
$\mathrm{Cu}, \mathrm{Pb}$, dan $\mathrm{Fe}$ dalam air di ketiga waduk tersebut masih dalam kisaran baku mutu air untuk perikanan budi daya air tawar sesuai dengan Peraturan Pemerintah RI Nomor 82 Tahun 2001 tentang Pengelolaan Kualitas Air dan Pengendalian Pencemaran (Lampiran 1). Namun demikian dilihat dari batas toleransinya bagi biota air, tingkat konsentrasi beberapa logam berat antara lain $\mathrm{Fe}, \mathrm{Cu}, \mathrm{Cd}$, dan $\mathrm{Cr}$, perlu diwaspadai (Lampiran 2). 


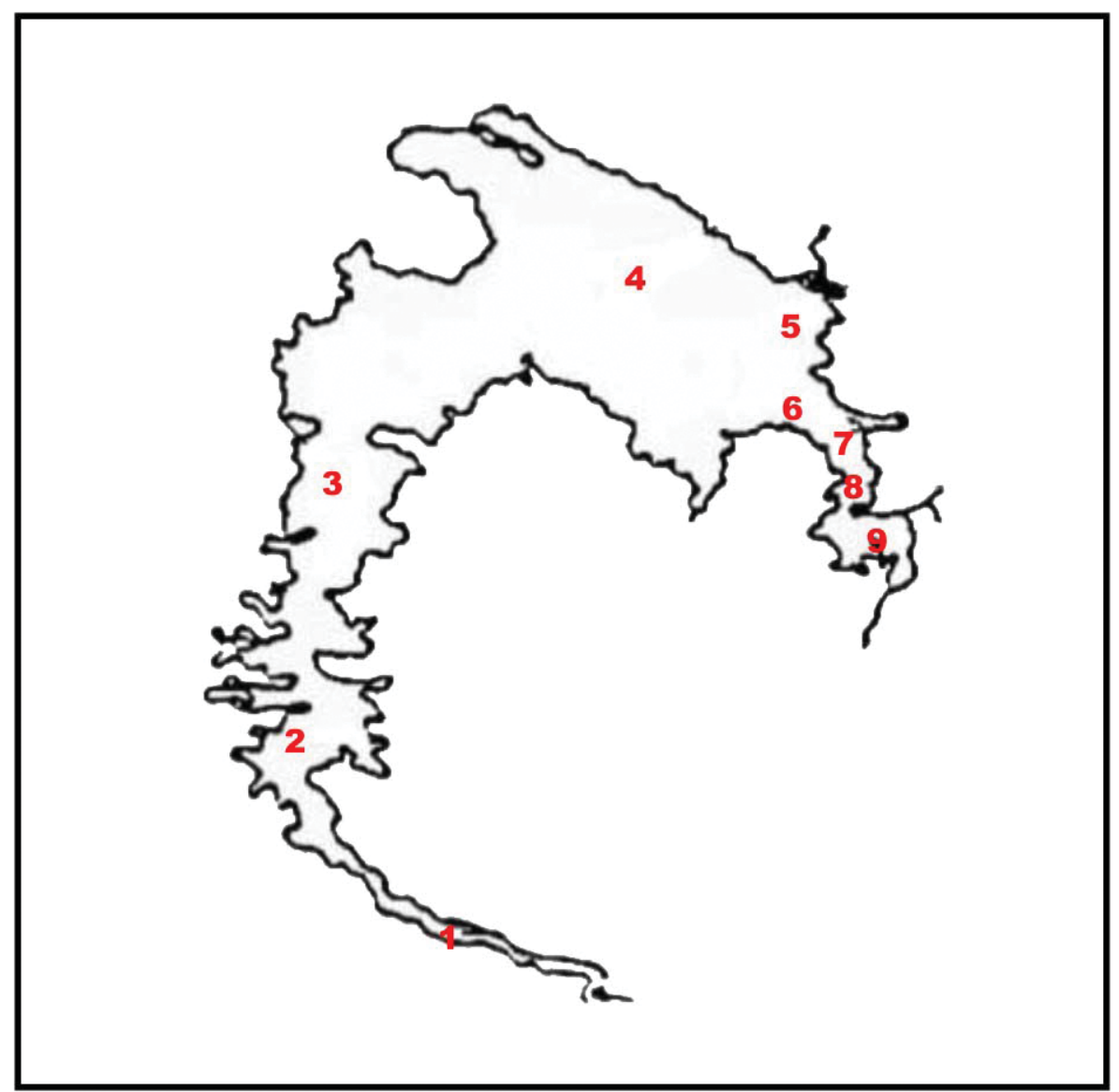

Keterangan (Remark):

Luas waduk 8.300 ha (Reservoir area is 8,300 ha)

1. Parung Kalong

2. Sodong

3. Jamaras

4. Baras Barat

5. Dam Utama

6. Keramba

7. Taroko

8. PDAM

9. Cilalawi

Gambar 3. Lokasi pengambilan contoh air, lumpur, dan ikan di Waduk Jatiluhur

Figure 3. Sampling location of water, mud and fish at Jatiluhur reservoir

Secara umum tingkat konsentrasi residu logam berat di Waduk Cirata lebih tinggi dibandingkan dengan di Waduk Jatiluhur dan Saguling. Tingkat konsentrasi residu masingmasing logam berat tersebut dalam tiap waduk juga bervariasi, seperti berikut:

$\mathrm{Mn}$ : Saguling $>$ Cirata $>$ Jatiluhur
Cd : Jatiluhur $>$ Cirata $>$ Saguling

$\mathrm{Cr} \quad$ : Cirata $>$ Jatiluhur $>$ Saguling

$\mathrm{Cu}$ : Cirata $>$ Saguling $>$ Jatiluhur

$\mathrm{Pb}$ : Jatiluhur $>$ Saguling $>$ Cirata

Fe : Cirata $>$ Jatiluhur $>$ Saguling

Konsentrasi residu logam berat tertinggi adalah Fe yang tercatat di Waduk Cirata (1,32- 


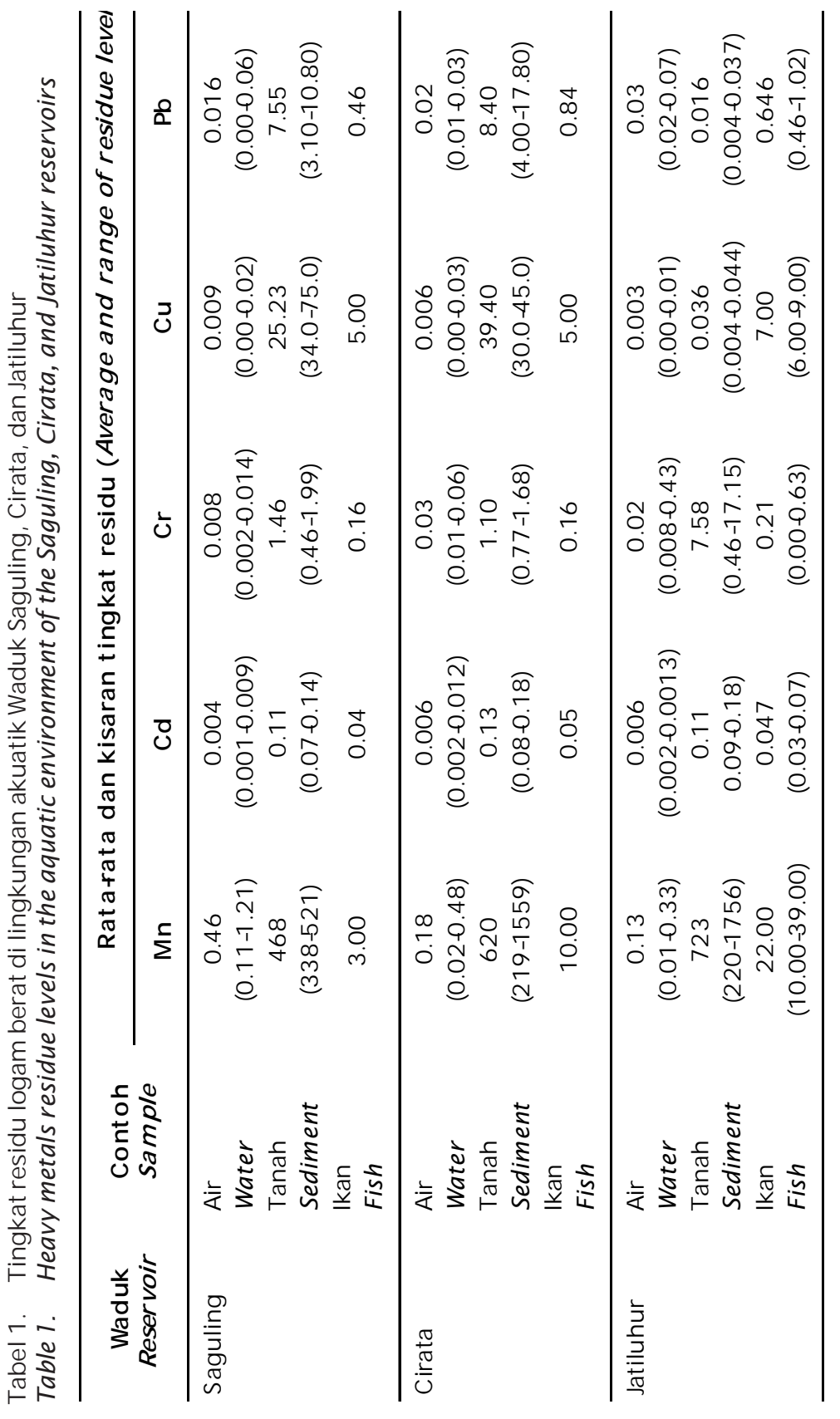


$7,11 \mathrm{mg} / \mathrm{L})$, menyusul Mn di Waduk Saguling $(0,11-1,21 \mathrm{mg} / \mathrm{L})$. Tingginya konsentrasi residu logam berat dapat disebabkan pula oleh sifat fisika dan kimia senyawa unsur tersebut, antara lain kelarutannya dalam air. Kehadiran persenyawaan tembaga $(\mathrm{Cu})$ misalnya, tergantung pada $\mathrm{pH}$ dan kandungan garam dalam air. Dalam lingkungan akuatik senyawa logam berat ini dapat mengalami siklus biologis dalam biota air, khususnya ikan yang menimbulkan proses bioakumulasi (Ariesyadi \& Slamet, 2000).

Residu logam berat pada ikan dari ketiga waduk umumnya tercatat melebihi konsentrasi yang biasa terdeteksi dalam ikan, khususnya residu $\mathrm{Mn}$ dan $\mathrm{Cu}$ tercatat relatif kritis (Lampiran 6), akan tetapi masih dapat dikonsumsi dengan aman, karena masih ada di bawah ambang batas toleransi (Lampiran 5). Data residu pada ikan di Waduk Saguling dan Cirata hanya dilakukan pada sampel ikan hasil budi daya karena tidak diperoleh sampel ikan hasil tangkapan, sedangkan di Jatiluhur analisis residu dilakukan pada ikan budi daya dan hasil tangkapan.

Menurut Forstner \& Whittmann (1981), sekuen konsentrasi $\mathrm{Cd}$ dan $\mathrm{Pb}$ dalam suatu ekosistem sungai adalah sebagai berikut: Air > ikan > sedimen > invertebrata akuatik.

Residu logam berat dalam sedimen di ketiga waduk umumnya tercatat dalam batasbatas komposisi yang umum terdapat dalam tanah dan sedimen (Lampiran 7). Konsentrasi logam dalam sedimen lebih tinggi dibandingkan dalam air dan ikan, mengikuti sekuen yang telah disampaikan di atas. Residu logam berat yang dianalisis dalam sedimen waduk tidak hanya berasal dari cemaran akan tetapi juga dari kandungan tanah dasar waduk.

Waduk Saguling, Cirata, dan Jatiluhur terletak di Sungai Citarum yang berhulu di wilayah pertanian kaki Gunung Wayang (40 km sebelah utara kota Bandung), dan mengalir ke arah utara sepanjang $225 \mathrm{~km}$ untuk bermuara di Laut Jawa. Sungai tersebut membelah daerah aliran sungai yang terdiri atas berbagai ekosistem, wilayah pertanian, pemukiman kampung, dan perkotaan (Djuangsih \& Dalim, 1994). Di sepanjang DAS Citarum tersebut pembangunan industri meningkat dengan tajam sejak tahun 1975, khususnya industri tekstil yang berjumlah sekitar 458 . Jenis industri lainnya adalah pengolahan kulit, kertas, cat, bahan kimia, farmasi, mesin, dan logam, yang berjumlah sekitar 490 unit
(Brotoisworo, 1990). Oleh karena itu, tidaklah mengherankan bila ketiga waduk tersebut menerima beban polusi yang cukup tinggi dari areal sekitarnya. Sebagai contoh dari salah satu tempat penyaringan limbah di Kota Bandung saja, terdeteksi kandungan logam berat $\mathrm{Fe}, \mathrm{Mn}, \mathrm{Cu}, \mathrm{Cr}, \mathrm{Pb}$, dan $\mathrm{Cd}$, sebanyak masing- masing 15,7 mg/ L; 0,25 mg/ L; 0,07 mg/ $\mathrm{L}$; $0,12 \mathrm{mg} / \mathrm{L} ; 0,91 \mathrm{mg} / \mathrm{L}$; dan 0,06 $\mathrm{mg} / \mathrm{L}$ (Anonim, 1991). Waduk Saguling dan Cirata terletak tidak jauh dari wilayah perkotaan, oleh karena itu dapat diasumsikan bahwa tingkat pencemaran logam dalam air Waduk Saguling $>$ Cirata > Jatiluhur. Hasil pemeriksaan pencemaran limbah kota, pencemaran logam berat di perairan waduk juga tergantung pada berbagai faktor lainnya, seperti faktor geofisika, fisika, kimia, dan sosial.

Menurut Brotoisworo (1990), sekitar 20\% pupuk inorganik yang digunakan di sawah tercuci (terbawa) ke Waduk Cirata dan Saguling. Kandungan unsur nitrogen dan fosfor yang tinggi ini memacu pertumbuhan gulma air Eichornia crassipes, Hydrilla verticillata, dan Salvinia molesta di ketiga waduk tersebut. Hal ini dapat menyebabkan penurunan tingkat pencemaran logam berat di suatu ekosistem akuatik. Menurut Forstner \& Wittmann (1984) tanaman tinggi melalui akarnya dapat menyerap unsur- unsur logam yang terikat dalam sedimen lebih baik dari alga dan lumut. Penggunaan satu spesies tanaman air di beberapa lokasi adalah cara yang baik untuk memonitor tingkat pencemaran logam berat.

Faktor-faktor lain yang mendukung sekuen tingkat pencemaran logam berat di ketiga waduk tersebut adalah cara pelaksanaan pengelolaan perairan, intensitas budi daya perikanan, dan tingkat aktivitas manusia di sekitar ekosistem waduk.

\section{KESIMPULAN}

- Tingkat konsentrasi logam berat Mn, Cd, Cr, $\mathrm{Cu}, \mathrm{Pb}$, dan Fe di tiga Waduk Saguling, Cirata, dan Jatiluhur masih sesuai dengan baku mutu air untuk perikanan budi daya air tawar (Peraturan Pemerintah RI No. 82 Tahun 2001).

- Secara potensial tingkat pencemaran residu logam berat di tiga waduk adalah sebagai berikut: Cirata > Saguling > Jatiluhur.

- Tingkat konsentrasi logam berat Fe $>M n>$ $\mathrm{Cr}>\mathrm{Pb}>\mathrm{Cu}>\mathrm{Cd}$.

- Jumlah residu logam berat dalam air < ikan < sedimen. 


\section{DAFTAR PUSTAKA}

Anonim. 1991. Pengelolaan air limbah di Pusat Pengelolaan Limbah di Pasir Impun. Universitas Pajajaran, Bandung. $27 \mathrm{pp}$.

Ariesyadi, H.D. dan J.S. Slamet. 2000. Ekokinetika tembaga di perairan statis. Jurnal Toksikologi. 1(1): 1-12.

Brotoisworo, I. 1990. Country Experience in River/ Lake Basin Management Focused on Water Quality. Institute of Ecology, Padjadjaran University, Bandung. 89 pp.

Darmono. 1990. “Uptake of Cadmium and Nickel in Banana Prawn merguiensis De Man". Bull. Environmn. Contamin. Toxicol. 45(3): 320328.

Darmono. 2001. Lingkungan Hidup dan Pencemaran, Hubungannya dengan Toksikologi Senyawa Logam. Penerbit Universitas Indonesia (UI- Press). p. 86-93.

Djuangsih, N. and H. Dalim. 1994. Preliminary study on the environmental pollution in the Citarum River basin, West Java, Indonesia. Dalam: Environmetal Toxicology in South East Asia. Widianarko e. al. Eds. VU University Press, Amsterdam. p. 277-288.

Forstner, U. and G.T.W. Wittmann. 1984. Metal pollution in The Aquatic Environment. $2^{\text {nd }}$ edition. Springer- Verlag, Berlin- Heidel bergNew York. 1981. p. 271-318.

Kumar, S. and S.C. Pant. 1994. Comparative effects of sublethalpoisoning of $\mathrm{Zn}, \mathrm{Cu}$, and $\mathrm{Pb}$ on gonads of the teleost, Puntius conchonius. Tox.Letters. 23: 189-194.

Sutamihardja, R.T.M. 2001. Kumpulan Makalah Toksikologi Lingkungan, Angkatan XIX. Program Pasca Sarjana. Program Studi IImu Lingkungan. Universitas Indonesia. 241 pp.

Suwarna, S., S. Surtipanti, dan S. Yatim. 1981. Studi kandungan logam berat $\mathrm{Hg}, \mathrm{Pb}, \mathrm{Cd}$, dan $\mathrm{Cr}$ dalam beberapa jenis hasil laut segar. Majalah BATAN 1(April). p. 2-8. 


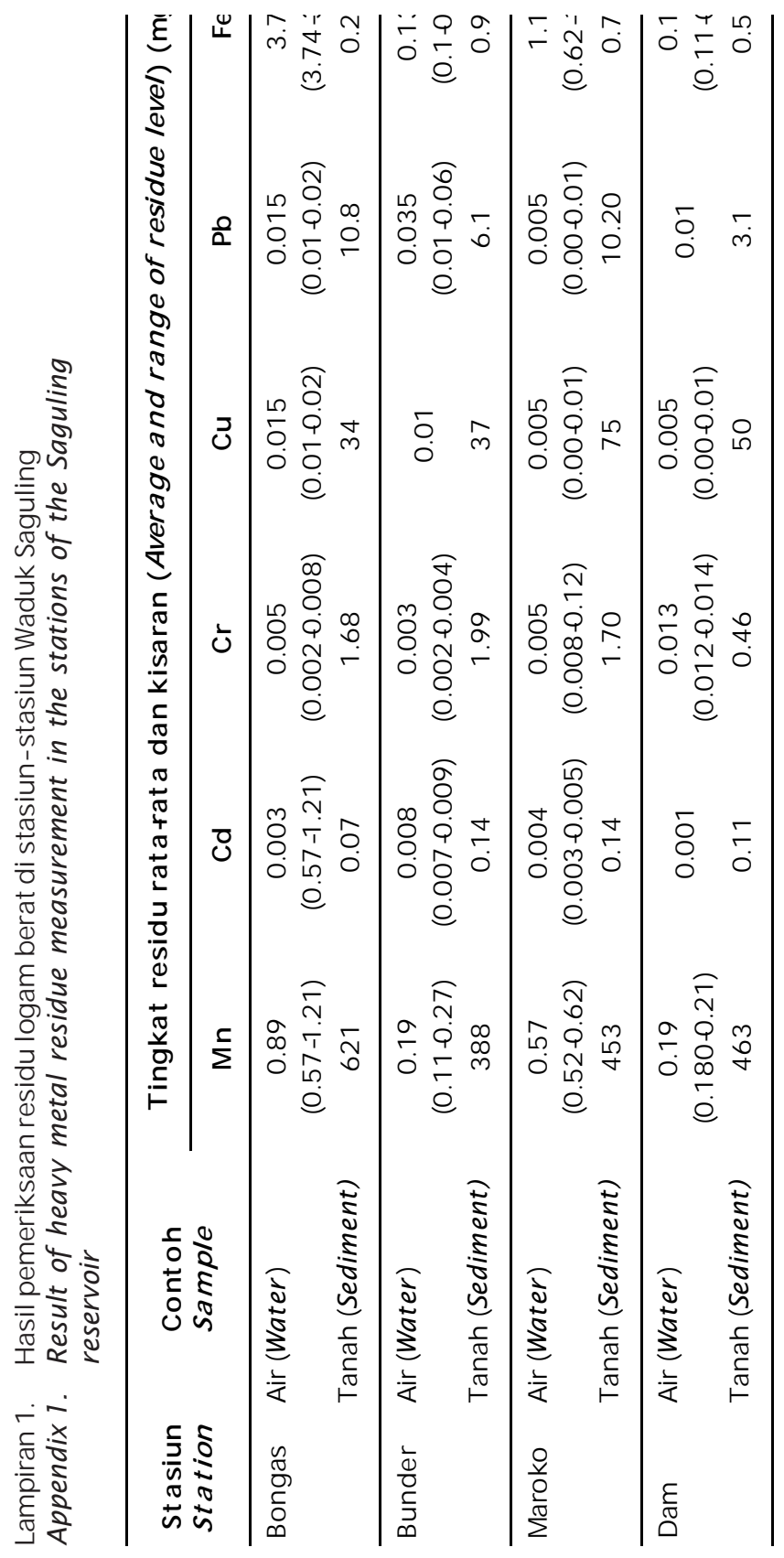




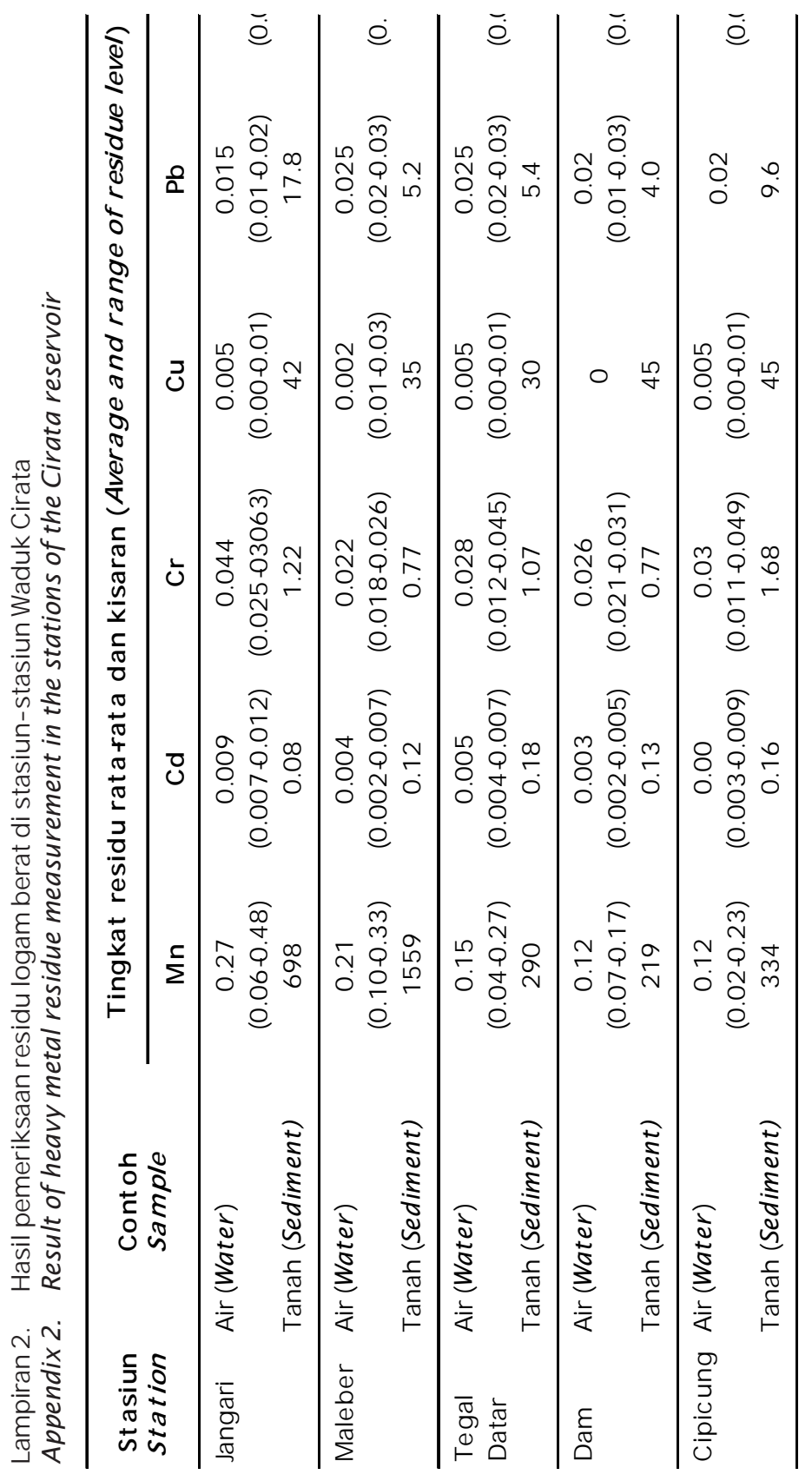




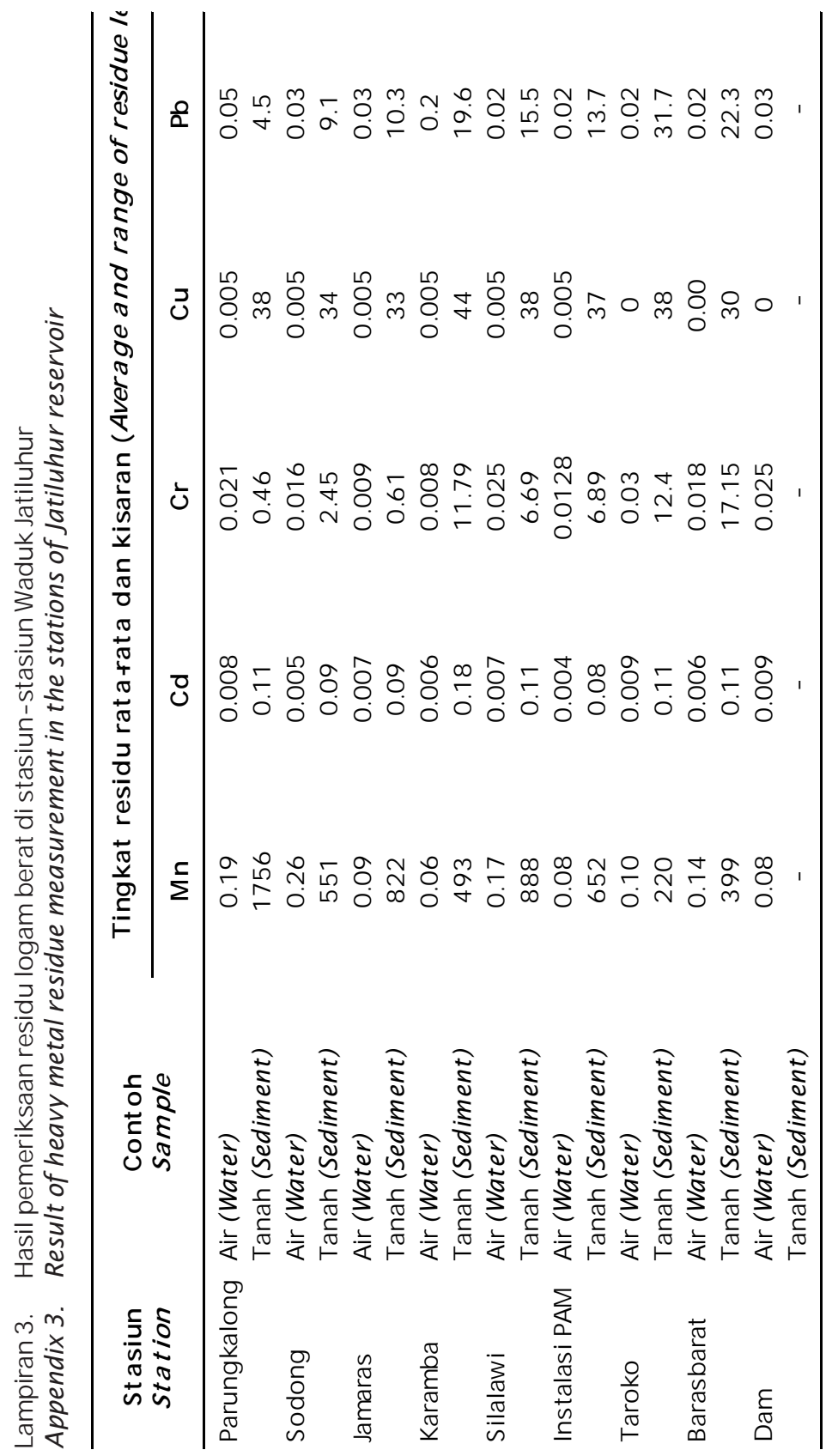


Lampiran 4. Baku mutu air untuk beberapa logam berat Appendix 4. Water quality standards for some heavy metals

\begin{tabular}{lccccc}
\hline \multirow{2}{*}{$\begin{array}{c}\text { Parameter } \\
\text { Parameter }\end{array}$} & $\begin{array}{c}\text { Satuan } \\
\text { Unit }\end{array}$ & \multicolumn{4}{c}{ Kelas (Class) } \\
\cline { 3 - 6 } & & I & II & III & IV \\
\hline $\mathrm{Cd}$ & $\mathrm{mg} / \mathrm{L}$ & 0.01 & 0.01 & 0.01 & 0.01 \\
$\mathrm{Cr}$ & $\mathrm{mg} / \mathrm{L}$ & 0.05 & 0.05 & 0.05 & 1 \\
$\mathrm{Cu}$ & $\mathrm{mg} / \mathrm{L}$ & 0.02 & 0.02 & 0.02 & 0.2 \\
$\mathrm{Fe}$ & $\mathrm{mg} / \mathrm{L}$ & 0.3 & - & - & - \\
$\mathrm{Pb}$ & $\mathrm{mg} / \mathrm{L}$ & 0.03 & 0.03 & 0.03 & 1 \\
$\mathrm{Mn}$ & $\mathrm{mg} / \mathrm{L}$ & 0.1 & - & - & - \\
\hline
\end{tabular}

Sumber (Source):

Peraturan Pemerintah Republik Indonesia Nomor 82 Tahun 2001 tentang Pengelolaan Kualitas Air dan Pengendalian Pencemaran Government Regulation of the Republic of Indonesia, Number 82 Year 2001 on The Management of Water Quality And Pollution Control

Lampiran 5. Batas toleransi konsentrasi beberapa unsur dan senyawa logam berat Appendix 5. Toxicological tolerance levels of some heavy metals and compounds

\begin{tabular}{lccc}
\hline $\begin{array}{c}\text { Unsur/Senyawa } \\
\text { Element/Compound }\end{array}$ & $\begin{array}{c}\text { Krustase } \\
\text { Crustaceans }(\boldsymbol{\mu g} / \mathbf{L})\end{array}$ & $\begin{array}{c}\text { Ikan } \\
\text { Fish }(\boldsymbol{\mu g} / \mathbf{L})\end{array}$ & $\begin{array}{c}\text { Manusia } \\
\text { Man }(\mathbf{m g} / \mathbf{~ k g})\end{array}$ \\
\hline $\mathrm{Cd}^{++}\left[\mathrm{CdCl}_{2}\right]$ & $0.03-0.4$ & 3 & $50-500$ \\
$\mathrm{Cr}^{++}\left[\mathrm{Cr}_{2}\left(\mathrm{SO}_{4}\right)_{3}\right]$ & $0.03-0.1$ & $1.2-200$ & $500-5,000$ \\
$\mathrm{Cu}^{++}\left[\mathrm{CuSO}_{4}\right]$ & $0.08-0.8$ & $0.03-0.8$ & $8,000 \mathrm{mg}$ \\
$\mathrm{Fe}^{++}\left[\mathrm{FeSO}_{4}\right]$ & $1.62-152$ & $0.9-152$ & $500-5,000$ \\
$\mathrm{Mn}+$ & $500-1,000$ & $50-1,200$ & $500-5,000$ \\
$\mathrm{~Pb}+\left[\mathrm{Pb}\left(\mathrm{NO}_{3}\right)_{2}\right]$ & $3-170$ & $0.33-200$ & 2,000 \\
\hline
\end{tabular}

Sumber (Source): Jung \& Liebmann dalam Forstner \& Wittmann (1981)

Lampiran 6. Kisaran umum konsentrasi logam dalam tubuh ikan Appendix 6. Common concentration ranges for heavy metals in fish

\begin{tabular}{|c|c|c|}
\hline Logam (Metal) & Kisaran (Range) $(\mu \mathrm{g} / \mathrm{kg})$ & Jaringan tubuh (Organ) \\
\hline Kadmium (Cadmium) (Cd) & - & - \\
\hline Krom (Chromium) (Cr) & $0.02-1.60$ & Otot (Muscle) \\
\hline Tembaga (Copper) (Cu) & $0.07-1.28$ & Otot (Muscle) \\
\hline Besi (Iron) (Fe) & $0.1-1.78$ & Otot (Muscle) \\
\hline Timbal (Lead) (Pb) & 2.0 & Total ikan (Whole fish) \\
\hline Mangan (Manganesa) (Mn) & $0.421-2.98$ & Otot (Muscle) \\
\hline
\end{tabular}

Sumber (Source): Forstner \& Wittmann (1981) 
Lampiran 7. Komposisi umum unsur logam dalam sedimen dan tanah Appendix 7. Common elemental composition of sediments and soils

\begin{tabular}{lc}
\hline \multicolumn{1}{c}{ Unsur (Element) } & Kisaran (Range) (mg/ kg) \\
\hline Kadmium (Cadmium) (Cd) & $0.05-0.22$ \\
Krom (Chromium) (Cr) & $11.0-72.0$ \\
Tembaga (Copper) (Cu) & $5.1-250$ \\
Besi (Iron) (Fe) & $17,000-65,000$ \\
Timbal (Lead) (Pb) & $5.7-150$ \\
Mangan (Manganesa) (Mn) & $460-6,700$ \\
\hline
\end{tabular}

Sumber (Source): Salomons \& Forstner (1984) 